\title{
Effects of reducing light-curing time of a high-power LED device on shear bond strength of brackets
}

\author{
Layene Figueiredo Almeida' (D) - Lidia Parsekian Martins ${ }^{1}$ (D) $\cdot$ Renato Parsekian Martins ${ }^{2,3}$
}

Received: 8 January 2018 / Accepted: 14 June 2018 / Published online: 31 July 2018

(c) Springer Medizin Verlag GmbH, ein Teil von Springer Nature 2018

\begin{abstract}
Purpose To assess the effects of reducing the curing time of a high-power light-emitting diode (LED) unit (Valo, Ultradent, South Jordan, UT, USA) on shear bond strength (SBS) of metal brackets and on the amount of adhesive remnant of two orthodontic composites.

Methods Eighty human premolars were divided into four groups (G1-4) according to curing time and composite: G1 (Transbond XT, 6s), G2 (Opal Bond MV, 6s), G3 (Transbond XT, 3s), and G4 (Opal Bond MV, 3s). Twenty-four hours after bonding, brackets were subject to a SBS test performed with a universal testing machine. Enamel surface was analyzed by SEM and the amount of adhesive remnant was assessed by the Image $\mathbf{J}$ software area calculation tool. Two-way analysis of variance was used for statistical analysis of SBS data, while Friedman and Mann-Whitney post hoc tests were used to analyze data on the amount of adhesive remnant.

Results Time and composite significantly affected SBS $(p<0.001)$. The $6 \mathrm{~s}$ curing showed a higher SBS value $(21.56 \mathrm{MPa})$ in comparison to $3 \mathrm{~s}$ curing (15.79 MPa). Transbond XT composite showed a significantly higher SBS value (21.06 MPa) compared to Opal Bond MV (16.29 MPa). After the SBS test, Opal Bond MV showed a significantly greater amount of composite adhered to enamel $(p<0.001)$.

Conclusion Reducing exposure time from 6 to $3 \mathrm{~s}$ significantly decreased mean values of SBS, even with the use of a high-power LED unit. Reduction in time did not affect the amount of adhesive remnant.
\end{abstract}

Keywords Light curing of dental adhesives · Orthodontic brackets · Dental bonding $\cdot$ Dental enamel $\cdot$ Dental cements

Layene Figueiredo Almeida, DDS, MS

layenea@gmail.com

Prof. Lidia Parsekian Martins, DDS, MS, PhD

lmartins@ foar.unesp.br

$\triangle$ Prof. Dr. Renato Parsekian Martins, DDS, MS, PhD

dr_renatopmartins@hotmail.com

1 Program of Orthodontics, Universidade Estadual Paulista, Araraquara, Brazil

2 Department of Orthodontics, Universidade Estadual Paulista, Araraquara, Brazil

3 Private practice, Rua Carlos

Gomes, 2158, 14801340 Araraquara, SP, Brazil 


\section{Auswirkungen der Verkürzung der Lichthärtezeit einer Hochleistungs-LED-Lampe auf die Scherbindungsfestigkeit von Brackets}

\section{Zusammenfassung}

Ziel Untersucht wurden die Auswirkungen der Verkürzung der Polymerisationszeit einer Hochleistungs-LED-Lampe (,light-emitting diode“; Valo, Ultradent, South Jordan/UT, USA) auf die Scherbindungsfestigkeit (SBS) von Metallbrackets und auf die Menge der verbliebenen Adhäsivreste von 2 kieferorthopädischen Kompositen.

Methoden Achtzig menschliche Prämolaren wurden in 4 Gruppen (G1-4) nach Aushärtezeit und Zusammensetzung eingeteilt: G1 (Transbond XT, 6s), G2 (Opal Bond MV, 6s), G3 (Transbond XT, 3 s) und G4 (Opal Bond MV, 3s). 24 h nach Bonding wurden die Brackets einem SBS-Test mittels Universalprüfmaschine unterzogen. Die Schmelzoberfläche wurde rasterelektronenmikroskopisch untersucht und die Menge der Kunststoffreste mittels des Flächenberechnungstools Image J ermittelt. Für die statistische Analyse der SBS-Daten diente die 2-way ANOVA, die Adhäsivreste wurden mit den Post-hoc-Tests von Friedman und Mann-Whitney ausgewertet.

Ergebnisse Sowohl Polymerisationszeit als auch Komposit nahmen signifikanten Einfluss auf die Scherbindungsfestigkeit $(p<0,001)$. Die Polymerisationszeit von 6s ergab einen durchschnittlich höheren SBS-Wert (21,6 MPa) im Vergleich zur kürzeren Aushärtung von 3s (15,8 MPa). Der durchschnittliche SBS-Wert von Transbond XT lag mit 21,1 MPa signifikant höher als der von Opal Bond MV (16,3 MPa). Opal Bond MV hinterließ nach dem SBS-Test eine größere Menge Komposit auf dem Schmelz $(p<0,001)$.

Fazit Nach verkürzter Polymerisationszeit von 3 s fielen die durchschnittlichen SBS-Werte signifikant niedriger aus. Die verkürzte Polymerisationszeit nahm keinen Einfluss auf die Menge der verbliebenen Adhäsivreste.

Schlüsselwörter Lichthärtung von dentalen Adhäsiven · Kieferorthopädische Brackets · Bonding · Zahnschmelz · Zahnzemente

\section{Introduction}

Bracket bonding is one of the most time-consuming procedures in orthodontics. For this reason, reducing the time required for light curing of composites would increase treatment efficiency and provide patients with greater comfort. Light-emitting diode(LED)-based units are the most commonly used curing devices and have been reported to achieve satisfactory results with significantly reduced light-curing times of $10[9,18,27]$ and $8 \mathrm{~s}$ [31]. However, studies that have reported a decrease in curing times were conducted with LED devices with a light intensity of $1000 \mathrm{~mW} / \mathrm{cm}^{2}$, which might suggest that devices with an intensity of about $3200 \mathrm{~mW} / \mathrm{cm}^{2}$ [17] could further reduce the light-curing times.

It was recently shown that a $1520 \mathrm{~mW}$ LED (producing a light intensity of $3200 \mathrm{~mW} / \mathrm{cm}^{2}$, according to the manufacturer) can achieve close to $90 \%$ composite conversion in $3 \mathrm{~s}$, depending on the type of composite cured [1] (60\% conversion is considered adequate). A clinical trial has also shown that brackets could be bonded using a $6 \mathrm{~s}$ cure with such a device [30]. However, the shear bond strength (SBS) of brackets subject to an even larger reduction of light-curing time, such as $3 \mathrm{~s}$, by high-power LED has not been tested. Moreover, the types of adhesive failures during bracket debonding have not been evaluated.

Thus, the aim of the present study is to assess the effects of reducing the curing time using a high-power LED device on the adhesion strength of metal brackets in vitro and on the adhesive remnant of two orthodontic composites.

\section{Materials and methods}

The sample size calculation was carried out using average (M) and standard deviation (SD) data from the literature $(\mathrm{M}=9.5, \mathrm{SD}=43$ [19], $\mathrm{M}=4.99, \mathrm{SD}=1.00$ [8]). Setting a significance level of $5 \%$ and power at $80 \%$, sample sizes of 10 and 18 teeth were calculated; however, a larger sample with two additional teeth $(10 \%)$ was chosen due to the possible occurrence of fractures.

A total of 80 human premolars that had not previously had bonded brackets and with buccal surfaces that were free of caries, fracture, and restoration were collected from the universities' tooth bank and randomly divided into four groups to be subjected to the various bonding protocols. This investigation was approved by the ethics and research committee of the Faculdade de Odontologia de Araraquara-UNESP (CAAE: 32126914.5.0000.5416). The teeth were stored in distilled water at $4{ }^{\circ} \mathrm{C}$ for no longer than 3 months according to ISO standard 11405:2015.

In group 1, brackets were bonded with Transbond XT (3M/Unitek ${ }^{\mathrm{TM}}$, Monrovia, CA, USA) along with its adhesive, while in group 2, Opal Bond MV composite and Opal Seal adhesive (OPAL Orthodontics, Ultradent, South Jordan, UT, USA) were used. A $6 \mathrm{~s}$ ( $3 \mathrm{~s}$ mesially and $3 \mathrm{~s}$ 
Table 1 Description of the groups tested

Tab. 1 Beschreibung der untersuchten Gruppen

\begin{tabular}{llll}
\hline Group & Adhesive system & $\begin{array}{l}\text { Light-curing time } \\
(\mathrm{s})\end{array}$ & $n$ \\
\hline 1 & $\begin{array}{l}\text { Transbond XT compos- } \\
\text { ite + adhesive }\end{array}$ & 6 & 20 \\
& Opal Bond + Opal Seal & 6 & 20 \\
3 & $\begin{array}{l}\text { Transbond XT compos- } \\
\text { ite + adhesive }\end{array}$ & 3 & 20 \\
4 & Opal Bond + Opal Seal & 3 & 20 \\
\hline
\end{tabular}

Table 2 Two-way ANOVA outcomes, in which the influence of light-curing time and the type of composite were assessed for shear bond strength

Tab. 2 Two-way ANOVA zur Untersuchung des Einflusses der Polymerisationszeit und der Art des Komposits auf die Scherbindungsfestigkeit

\begin{tabular}{llll}
\hline Factor & Mean square & $\mathrm{F}$ & $p$-value \\
\hline Time & 453.96 & 17.42 & $<0.001$ \\
Composite & 667.19 & 25.60 & $<0.001$ \\
Time*Composite & 4.88 & 0.19 & 0.67 \\
\hline
\end{tabular}

Table 3 Mean, standard deviation (SD), and confidence interval (95\%) values for the variables time and composite (in MPa)

Tab. 3 Mittelwert, Standardabweichung (SD) und Konfidenzintervall (95\%) für die Variablen Zeit und Komposit (in MPa)

\begin{tabular}{|c|c|c|c|c|c|}
\hline \multirow[t]{2}{*}{ Variables } & & \multirow[t]{2}{*}{ Mean } & \multirow[t]{2}{*}{ SD } & \multicolumn{2}{|c|}{ Confidence interval } \\
\hline & & & & $\begin{array}{l}\text { Lower } \\
\text { limit }\end{array}$ & $\begin{array}{l}\text { Upper } \\
\text { limit }\end{array}$ \\
\hline \multirow[t]{2}{*}{ Time } & 3 & 15.79 & 5.52 & 14.18 & 17.40 \\
\hline & 6 & 21.57 & 5.65 & 19.96 & 23.17 \\
\hline \multirow[t]{2}{*}{ Composite } & $\begin{array}{l}\text { Transbond } \\
\text { XT }\end{array}$ & 21.06 & 6.31 & 19.45 & 22.67 \\
\hline & $\begin{array}{l}\text { Opal } \\
\text { Bond }\end{array}$ & 16.30 & 5.31 & 14.69 & 17.90 \\
\hline
\end{tabular}

Table 4 Outcomes of shear bond strength (SBS) averages of the groups tested, along with the standard deviation (SD), and minimum $(\min )$ and maximum $(\max )$ values (MPa)

Tab. 4 Ergebnisse der SBS-Mittelwerte der untersuchten Gruppen, Standardabweichung (SD) sowie minimale ( $\min$ ) und maximale (max) Werte (MPa)

\begin{tabular}{lllllll}
\hline Group & Time & \multicolumn{2}{l}{ Composite Mean } & SD & Min & Max \\
\hline 1 & 6 & TB & 23.70 & 6.51 & 11.20 & 37.56 \\
2 & 6 & OB & 19.43 & 3.70 & 12.21 & 28.37 \\
3 & 3 & TB & 18.42 & 4.96 & 6.58 & 26.33 \\
4 & 3 & OB & 13.16 & 4.85 & 6.88 & 21.71 \\
\hline
\end{tabular}

$T B$ Transbond XT, $O B$ Opal Bond

distally) light-curing procedure was used for both groups. In groups 3 and 4 , the same composites and adhesives were used, but they were light cured for $3 \mathrm{~s}$ on one surface only (Table 1). All adhesives were light cured for $3 \mathrm{~s}$ before the composites were cured either 6 or $3 \mathrm{~s}$, according to the respective group. The light-curing device was the VALO Cordless third-generation LED (Ultradent, South Jordan, UT, USA), using the Xtra curing mode (intensity was $3200 \mathrm{~mW} / \mathrm{cm}^{2}$ according to the manufacturer). Using a Fieldmaster energy meter (Coherent, Santa Clara, CA, USA), a power of $1757 \mathrm{~mW}$ was found, thus, resulting in an intensity of $2246 \mathrm{~mW} / \mathrm{cm}^{2}$, based on a $9.6 \mathrm{~mm}$ diameter tip. The LED unit was also evaluated for variation in power, which was not used in the present report.

The teeth were secured into $2 \mathrm{~cm}$-high and $20 \mathrm{~mm}$-round polyvinyl chloride (PVC) tubes, with self-curing acrylic resin (Resina acrílica JET, Produtos Odontológicos Clássico, São Paulo, BR). The center of the buccal surface was positioned perpendicular to the tube base with the aid of a metal set square and the specimens were stored in distilled water at $4{ }^{\circ} \mathrm{C}$ until bracket bonding, according to ISO/TS $11405 / 2014$.

Prior to bonding, enamel surfaces were cleaned with oilfree pumice paste and rubber cup for $15 \mathrm{~s}$, followed by rinsing with tap water and drying with water-free compressed air for $10 \mathrm{~s}$.

New Avex (Opal Orthodontics, South Jordan, UT, USA), Roth prescription, 0.018 in metal brackets with a $11.045 \mathrm{~mm}^{2}$ base (measured by a Coolant Proof Micrometer IP65 caliper, Mitutoyo, Aurora, IL, USA) were bonded to the premolars, following the respective bonding protocol for each group.

After bonding, specimens were immersed in distilled water and stored at $37^{\circ} \mathrm{C}$ for $24 \mathrm{~h}$ until SBS tests were carried out. A custom-made chisel was attached to an EMIC DL 2000 (INSTRON, ITW, São José dos Pinhais, BR) universal testing machine with $2500 \mathrm{~N}$ load cell and subjected to a vertical movement at a speed of $0.5 \mathrm{~mm} / \mathrm{min}$. Maximal SBS was registered in newton $(\mathrm{N})$ by the dedicated test script (TESC) software and calculated into megapascal (MPa) for statistical analysis.

After the test, the buccal surfaces were molded with light-body polyvinylsiloxane (Elite HD, Zhermack ${ }^{\circledR}$, Badia Polesine, IT), and impression copings were made with epoxy composite (Epofix, Struers, Ballerup, DK). In order to quantify adhesive remnant, copings were coated with a gold layer under a $50 \mathrm{~s}$ cycle and photographed by scanning electron microscopy (JSM, 6380LV, JEOL, Tokyo, JP) under $20 \times$ magnification and $12 \mathrm{kV}$ (Fig. 1). One operator determined the percentage of remaining composite adhered to teeth comparing it to the bracket base area, with the aid of the Image J software, v. 1.36 (National Institutes of Health, Rockville, MD, USA). Measurements were repeated after one week in order to conduct error analysis by the Bland-Altman plot $[5,13]$, and the mean value of both measures was used for statistical analysis.

Statistical analysis of the data was carried out by twoway analysis of variance (ANOVA) with the significance level set at $95 \%(p<0.05)$. Data on the percentage of ad- 

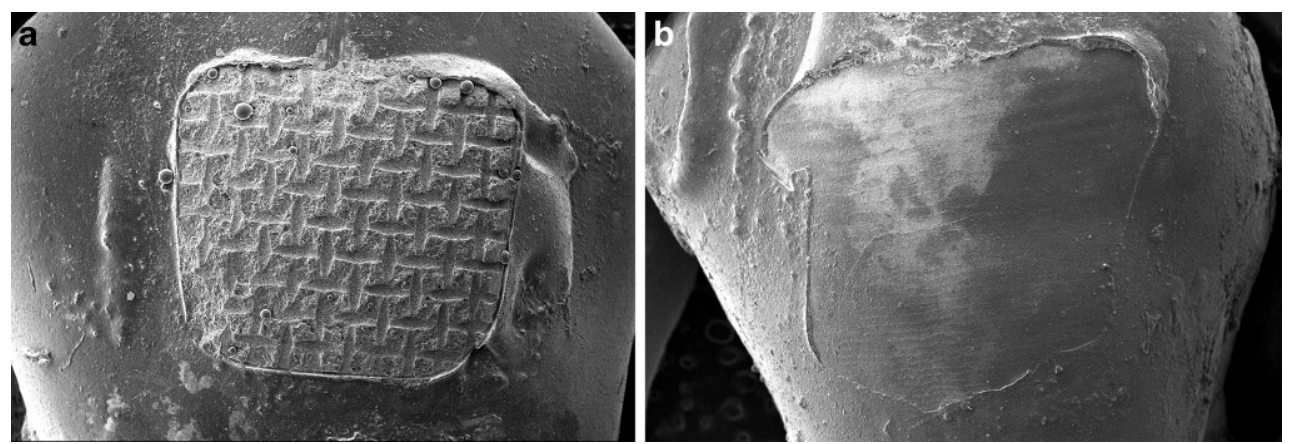

Fig. 1 a Scanning electron microscope (SEM) photograph under $20 \times$ magnification showing a specimen with almost $100 \%$ adhesive on the enamel surface. b SEM photograph with no adhesive on the enamel surface

Abb. 1 a Rasterelektronenmikroskopische Aufnahme, Vergr. 20:1, Probe mit nahezu 100\% Adhäsiv auf der Schmelzoberfläche. b Rasterelektronenmikroskopische Aufnahme, kein Adhäsiv auf der Schmelzoberfläche

Fig. 2 Adhesion strength in relation to the variables resin and time (s), showing no interaction Abb. 2 Scherbindungsfestigkeit in Relation zu den Variablen „resin“ und „Zeit“ (s). Es liegen keine Wechselwirkungen vor

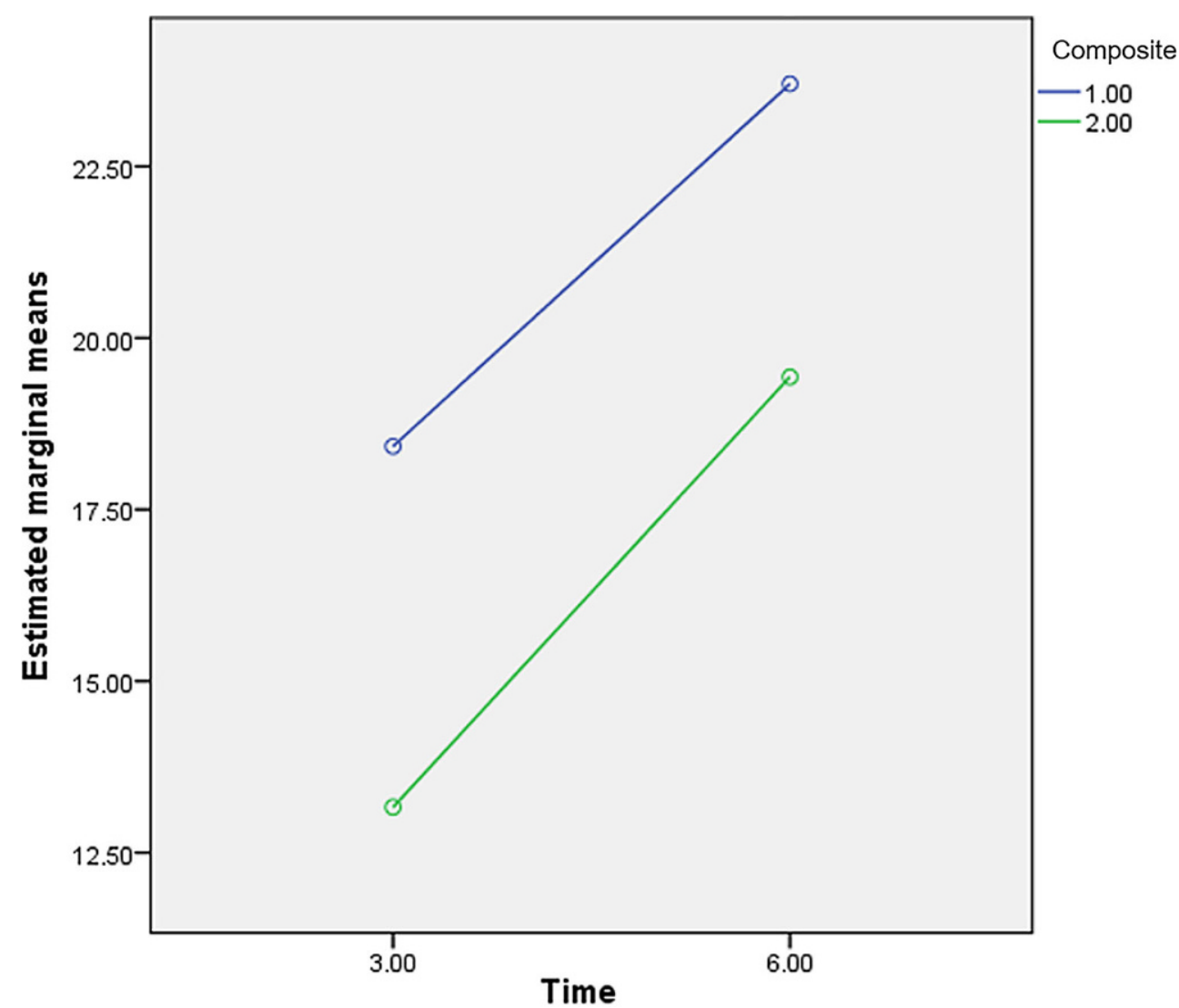

The type of composite significantly affected SBS values $(p<0.001$; Table 2$)$. Transbond XT composite produced a SBS of 21.06 MPa, whereas Opal Bond produced an average of $16.30 \mathrm{MPa}$ (Table 3 ). There was no interaction between the curing time and type of composite $(p=0.667$, Tables 2 and 4; Fig. 2).

Reproducibility of the process for measuring the amount of adhesive remnant was assessed by Bland-Altman plot (Fig. 3), estimated with $95 \%$ limits of agreement. Bias was 0.038 , and the calculated limits of agreement suggest $(p<0.001$; Table 2). The $3 \mathrm{~s}$ interval produced an average SBS of $15.79 \mathrm{MPa}$, whereas the $6 \mathrm{~s}$ interval produced an average of $21.57 \mathrm{MPa}$ (Table 3). 
Table 5 Mann-Whitney test was used to assess the influence of composite and time on the amount of remaining material on enamel surface $\left(p=0.025^{\mathrm{a}}\right)$

Tab. 5 Mann-Whitney-Test ermittelt den Einfluss von Komposit und Zeit auf die Menge des verbliebenen Adhäsivs auf der Schmelzoberfläche $\left(p=0,025^{\mathrm{a}}\right)$

\begin{tabular}{llllll}
\hline Variable & \multicolumn{3}{l}{ Percentage } & & $\begin{array}{l}\text { Mann-Whitney } \\
(p<0.025)\end{array}$ \\
& & 25 & $\begin{array}{l}50(\mathrm{Me}- \\
\text { dian })\end{array}$ & 75 & \\
\hline Composite & TB & 8.0 & 11.0 & 19.0 & $<0.001$ \\
& OB & 19.0 & 38.0 & 74.0 & \\
Time (s) & 3 & 9.0 & 18.0 & 44.0 & $p=0.509$ \\
& 6 & 13.2 & 21.5 & 39.2 & \\
\hline
\end{tabular}

${ }^{\mathrm{a}}$ Corrected by Bonferroni

$T B$ Transbond XT, $O B$ Opal Bond

Table 6 Distribution of fractures among groups Tab. 6 Verteilung von Frakturen auf die Gruppen

\begin{tabular}{llll}
\hline Group & $\begin{array}{l}\text { Number of } \\
\text { fractures }\end{array}$ & $\begin{array}{l}\text { Minimal } \\
\text { stress } \\
(\mathrm{MPa})\end{array}$ & $\begin{array}{l}\text { Maximal } \\
\text { stress } \\
(\mathrm{MPa})\end{array}$ \\
\hline 1 & 5 & 21.68 & 27.04 \\
2 & 1 & 21.36 & 21.36 \\
3 & 2 & 19.96 & 26.33 \\
4 & 0 & - & - \\
\hline
\end{tabular}

Table 7 Adhesive remnant index (ARI) data distribution for the four study groups

Tab. 7 ARI(Adhesive Remnant/Residual Index)-Datenverteilung für die 4 untersuchten Gruppen

\begin{tabular}{llllllllll}
\hline & \multicolumn{3}{c}{ ARI 0 } & \multicolumn{2}{c}{ ARI 1 } & \multicolumn{3}{c}{ ARI 2 } & \multicolumn{3}{c}{ ARI 3 } \\
Group & $N$ & $N$ & $\%$ & $N$ & $\%$ & $N$ & $\%$ & $N$ & $\%$ \\
\hline 1 & 15 & 0 & 0 & 15 & 100 & 0 & 0 & 0 & 0 \\
2 & 19 & 1 & 5 & 12 & 63 & 6 & 32 & 0 & 0 \\
3 & 18 & 1 & 5.5 & 16 & 89 & 1 & 5.5 & 0 & 0 \\
4 & 20 & 0 & 0 & 13 & 65 & 7 & 35 & 0 & 0 \\
\hline
\end{tabular}

that most measurements presented with differences between 0.24 and $-0.16 \mathrm{~mm}^{2}$.

Friedman test outcomes revealed significant differences between the four groups $(p=0.006)$ regarding the amount of adhesive remnant. The type of composite was significantly associated with the amount of adhesive remnant on the enamel surface ( $p<0.001$; Table 5). Opal Bond left more composite adhered to the tooth in comparison to Transbond XT (Table 5). There was no significant difference for the curing time $(p=0.509)$.

A total of eight specimens underwent fracture during the SBS test. The SBS registered in those specimens ranged from 19.96 to $27.4 \mathrm{MPa}$ and fracture was more frequent in G1 (Transbond XT, $6 \mathrm{~s}$; Table 6).

\section{Discussion}

Reducing exposure time from 6 to $3 \mathrm{~s}$ decreased bonding strength, even with the use of a high-power LED. This was an expected finding, since the degree of conversion for composites is directly proportional to the power absorbed by its photoactivators $[6,25]$. Reduction in time from 40 to $10 \mathrm{~s}$ [27], from 20 to $10 \mathrm{~s}$ [9, 18, 27, 29] and even to $8 \mathrm{~s}$ [31] have already been shown to produce clinically acceptable outcomes; however, curing was performed with lower power LED devices, producing light intensities of $1000 \mathrm{~mW} / \mathrm{cm}^{2}$. More recently in a split-mouth clinical trial, the effects of curing brackets with a high power LED for $6 \mathrm{~s}$ [30] were evaluated and no difference was found compared to brackets cured with conventional light. Importantly, we have shown in vitro that a further decrease could be possible, which needs confirmation before starting further clinical trials examining even lower curing times.

It is very important to mention that the "clinically acceptable" SBSs values very often reported in the literature (from 5.9-7.8 MPa) have been empirically based on one personal opinion from an article published in 1975 [22], a time when bonding materials and procedures differed from those used today, such as etching time and chemicals used, as well as the adhesive systems, with acrylic resin being one of the main bonding materials [22]. Due to a lack of better references on the ideal strength, it is difficult to determine the optimal adhesion parameter. An alternative value for those cited in the literature as ideal could be estimated from maximal biting force. If the adult maximal biting force $(285.01 \mathrm{~N}$ for men and $253.99 \mathrm{~N}$ for women) [28] is divided by the bracket base area used in the present study $\left(11.045 \mathrm{~mm}^{2}\right)$, the result, of 25.8 and $22.99 \mathrm{MPa}$ for men and women, respectively, would equal the maximal pressure value a single bracket would be subjected to if exposed to mastication. The SBS values found in this paper for 6 and $3 \mathrm{~s}$ were 21.57 and $15.79 \mathrm{MPa}$, respectively, and are below that estimated value, but significantly above the values of 5.9-7.8 MPa [22].

Nevertheless, while high bonding strengths are needed in order to keep orthodontic brackets in place during treatment, extremely high values might increase the risk for enamel fracture at the time of debonding. In our sample, eight fractures occurred in specimens subjected to the shear bond strength test. Five of them occurred after Transbond XT was cured for $6 \mathrm{~s}$, with SBS values ranging from 21.7 to $27.0 \mathrm{MPa}$; two occurred after Transbond XT was light cured for $3 \mathrm{~s}$, with values ranging from 20.0 to $26.3 \mathrm{MPa}$; and one occurred after Opal Bond MV was cured for $6 \mathrm{~s}$ with a SBS value of $21.36 \mathrm{MPa}$. Although the literature considers SBS values above $13 \mathrm{MPa}$ as an increased risk for enamel fracture $[3,7,21]$, we only found fractures with SBS values above 20 MPa. High values carry a risk for 


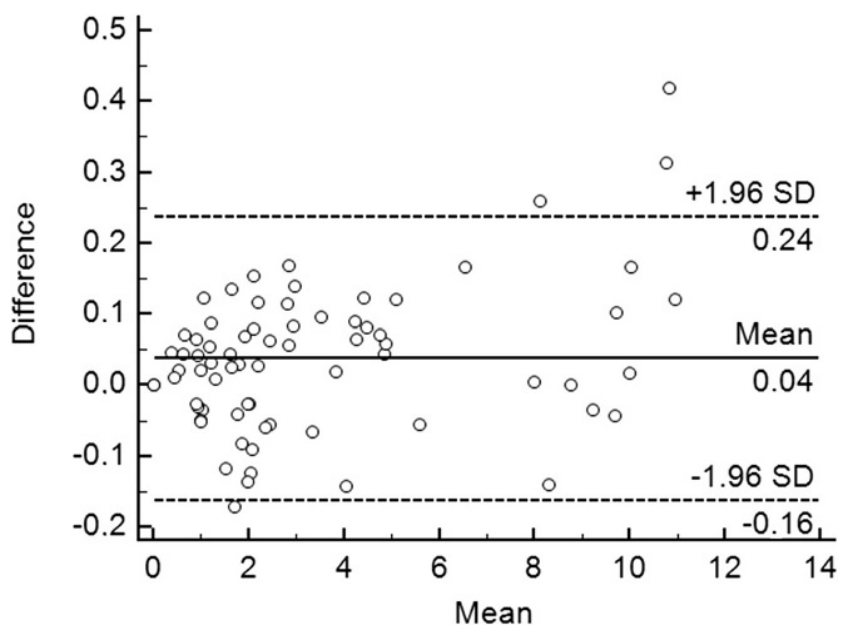

Fig. 3 Bland-Altman plot: association of the differences between the measured values and the mean values to assess reproducibility. $S D$ standard deviation

Abb. 3 Bland-Altman-Plot: Assoziation zwischen der Messwertdifferenzen und dem Mittelwert zur Beurteilung der Reproduzierbarkeit. $S D$ Standardabweichung

fracture at the time of debonding, but this finding should be considered with caution, since pure SBS is hardly ever applied to brackets to remove them clinically [4].

The type of composite affected SBS. Transbond XT showed a higher average SBS than Opal Bond MV at $6 \mathrm{~s}$ of curing and as curing time decreased this difference increased (Fig. 2 and Table 4). In general, composites tend to respond differently to curing since various factors affect that process, such as chemical composition and the type of lightcuring unit $[15,24]$. To date, no comparison between these two composites has been published using a high power LED with such a short curing time, even though their conversion degree has already been shown to be adequate after a curing time of $3 \mathrm{~s}$ [1]. Compared to what is considered adequate for immediate loading, i.e., 55\% conversion degree [14], both composites showed an adequate degree of conversion: Transbond XT had a conversion degree above $60 \%$ while Opal Bond MV had a conversion degree above $80 \%$.

The ISO/TS 11405:2015, as well as DIN 13990-1/-2 norms, suggest thermocycling with 500 cycles as one of the ways of storing teeth before mechanical testing, and it could have been a possible option in this study. However, while some studies have reported a significant decrease in strength values after thermocycling $[9,26]$, others have shown that thermocycling did not affect bond strength [11, 16, 23, 32]. These different results can be explained by the fact that conversion degree affects resin integrity when it is submitted to water storage and thermocycling. The reason for this effect is that inadequate light curing makes resin more permeable to water [12]. The adhesives used in this study showed a conversion degree above $60 \%$ even with a curing time of
$3 \mathrm{~s}$ [1], which leads us to believe that thermocycling would not have changed our results.

The decrease of curing time did not have any significant influence on the amount of residual composite after the SBS test, but differences were found between the two commercial brands. After the application of Opal Bond MV, a greater amount of adhesive remained on the enamel surface, revealing a safer pattern of failure (Tables 5 and 6) in comparison to Transbond XT. Adhesive failure between bracket and composite seems to be the safest pattern of failure because enamel fracture is avoided due to less stress being transmitted to enamel at the time of debonding [20]. In the present study, the amount of residual composite was estimated by determining its area and comparing it to the bracket base area. This method appears to be more accurate and reproducible than visual inspection and the adhesive remnant index (ARI) due to it being quantitative rather than qualitative [2]. Since this method has not yet been reported in the literature, we have adjusted the percentages into ARI score (Table 7) in order to promote discussion of the subject.

The majority of the specimens showed an ARI score of 1 , which means that less than $50 \%$ of composite remained on the enamel and is in agreement with previous reports where curing time was reduced with Transbond XT [18]. In contrast, similar studies [10, 31] found an ARI score of 3 (100\% of adhesive on enamel surface with bracket base printing), which did not occur in any of our groups tested. This is probably due to the fact that none of them used irradiances similar to the one used in this study.

In bracket bonding, it is imperative for adhesion to be strong enough to allow the bracket to remain in place until completion treatment, and at the same time allowing safe debonding. We believe that SBS values ranging from 5.9 to $7.8 \mathrm{MPa}$ are not high enough to bear masticatory forces and that a $6 \mathrm{~s}$ cure might produce an extremely high adhesion strength $(21.57 \mathrm{MPa})$, increasing the risk of enamel fracture. Reducing curing time to $3 \mathrm{~s}$ produced a similar SBS average (15.79 MPa) to previous studies working with a $10 \mathrm{~s}$ cure time (SBSs of 13.5 MPa [27], 14.48 MPa [9], and 15.9 MPa [18]) which might be safer values when it comes to avoiding enamel fracture. When cured for $3 \mathrm{~s}$, Opal Bond MV composite showed SBS values that were high enough but were not associated with enamel fracture, thus, seeming to have the best relationship when compared to the other groups. Nonetheless, we need to be careful when extrapolating these data directly to clinical practice because in vitro results might not directly reproduce the situation in the oral cavity. Therefore, we suggest that clinical studies be undertaken to confirm these in vitro results. 


\section{Conclusions}

- The shear bond strengths obtained at $6 \mathrm{~s}$ intervals were significantly greater than at $3 \mathrm{~s}$ intervals when using a high-power LED device.

- Transbond XT composite presented higher shear bond strength values in comparison to Opal Bond MV composite.

- Reduction in time did not affect the amount of adhesive remnant.

- After the SBS test, Opal Bond MV composite showed a significantly greater amount of composite adhered to the enamel surface.

\section{Compliance with ethical guidelines}

Conflict of interest L.F. Almeida, R. Parsekian Martins and L. Parsekian Martins declare that they have no competing interests.

Ethical standards All procedures performed in studies involving human participants were in accordance with the ethical standards of the institutional and/or national research committee and with the 1964 Helsinki declaration and its later amendments or comparable ethical standards.

\section{References}

1. Amato PAF, Martins RP, dos Santos Cruz CA et al (2014) Time reduction of light curing: Influence on conversion degree and microhardness of orthodontic composites. Am J Orthod Dentofacial Orthop 146(1):40-46

2. Artun J, Bergland S (1984) Clinical trials with crystal growth conditioning as an alternative to acid etch enamel pretreatment. Am J Orthod 85(4):333-340

3. Bishara SE (2003) Ceramic brackets: a clinical perspective. World J Orthod 4(1):61-66

4. Bishara SE, Fonseca JM, Fehr DE et al (1994) Debonding forces applied to ceramic brackets simulating clinical conditions. Angle Orthod 64(4):277-282

5. Bland J, Altman D (1986) Statistical methods for assessing agreement between two methods of clinical measurement. Lancet 1(8476):307-310

6. Blankenau R, Erickson RL, Rueggeberg F (1999) New light curing options for composite restorations. Compend Contin Educ Dent 20(2):122-125

7. Bowen RL, Rodriguez MS (1962) Tensile strength and modulus of elasticity of tooth structure and several restorative materials. J Am Dent Assoc 64:378-387

8. Carvalho PEG, Santos VM, Isber H et al (2013) Halogen light versus LED for bracket bonding: shear bond strength. Dental Press J Orthod 18(1):31e1-31e6. https://doi.org/10.1590/s217694512013000100007

9. Cerekja E, Cakirer B (2011) Effect of short curing times with a high-intensity light-emitting diode or high-power halogen on shear bond strength of metal brackets before and after thermocycling. Angle Orthod 81(3):510-516

10. Dall'Igna CM, Marchioro EM, Spohr AM et al (2011) Effect of curing time on the bond strength of a bracket-bonding system cured with a light-emitting diode or plasma arc light. Eur J Orthod 33(1):55-59

11. De Munck J, Van Landuyt K, Coutinho E et al (2005) Micro-tensile bond strength of adhesives bonded to class-I cavity-bottom dentin after thermo-cycling. Dent Mater 21(11):999-1007

12. De Munck J, Van Landuyt K, Peumans M et al (2005) A critical review of the durability of adhesion of tooth tissue: methods and results. J Dent Res 84(2):118-132

13. Donatelli RE, Lee SJ (2013) How to report reliability in orthodontic research: part 1. Am J Orthod Dentofacial Orthop 144(1):156-161

14. Eliades T, Eliades G, Brantley WA et al (1995) Residual monomer leaching from chemically cured and visible light-cured orthodontics adhesives. Am J Orthod Dentofacial Orthop 108(3):316-321

15. Ferracane J, Greener E (1984) The effect of composite formulation on the degree of conversion and mechanical properties of dental restorative composites. J Biomed Mater Res 20(1):121-131

16. Finnema KJ, Ozcan M, Post WJ et al (2010) In-vitro orthodontic bond strength testing: a systematic review and meta-analysis. Am J Orthod Dentofacial Orthop 137(5):615-622

17. Jandt K, Mills R (2013) A brief history of LED photopolymerization. Dent Mater 29(6):605-617

18. Lamper T, Steinhäuser-Andresen S, Huth KC et al (2012) Does a reduction of polymerization time and bonding steps affect the bond strength of brackets? Clin Oral Investig 16(2):665-671

19. Mavropoulos A, Staudt CB, Kiliaridis S et al (2005) Light curing time reduction. Eur J Orthod 27(4):408-412

20. Ogaard B, Fjeld M (2010) The enamel surface and bonding in orthodontics. Semin Orthod 16(1):37-48

21. Retief DH (1974) Failure at the dental adhesive-etched enamel interface. J Oral Rehabil 1(13):265-284

22. Reynolds JR (1975) A review of direct orthodontic bonding. Br J Orthod 2(3):171-178

23. Richter C, Jost-Brinkmann PG (2015) Shear bond strength of different adhesives tested in accordance with DIN 13990-1/-2 and using various methods of enamel conditioning. J Orofac Orthop 76(2):175-187. https://doi.org/10.1007/s00056-014-0281-1

24. Rueggeberg F (2011) State-of-the-art: dental photocuring-a review. Dent Mater J 27(1):39-52

25. Rueggeberg F, Jordan D (1993) Effect of light-tip distance on polymerization of composite. Int J Prosthodont 6(4):364-370

26. Sokucu O, Siso SH, Ozturk F, Nalcaci R (2010) Shear bond strength of orthodontic brackets cured with different light sources under thermocycling. Eur J Dent 4(3):257-262

27. Swanson T, Dunn WJ, Childers DE et al (2004) Shear bond strength of orthodontic brackets bonded with light-emitting diode curing units at various polymerization times. Am J Orthod Dentofacial Orthop 125(3):337-341

28. Takaki P, Vieira M (2014) Maximum bite force analysis in different age groups. Int Arch Otorhinolaryngol 18(3):272-276. https://doi. org/10.1055/s-0034-1374647

29. Thind BS, Stirrups DR, Lloyd CH (2006) A comparison of tungsten-quartz-halogen, plasma arc and light-emitting diode light sources for the polymerization of an orthodontic adhesive. Eur $\mathrm{J}$ Orthod 28(1):78-82

30. Ward JD, Wolf BJ, Leite LP et al (2015) Clinical effect of reducing curing times with high-intensity LED lights. Angle Orthod 85(6): 1064-1069

31. Yu HS, Lee KJ, Jin GC et al (2007) Comparison of the shear bond strength of brackets using the led curing light and plasma arc curing light: polymerization time. World J Orthod 8(2):129-135

32. Yuasa T, Iijima M, Ito S, Muguruma T, Saito T, Mizoguchi I (2010) Effects of long-term storage and thermocycling on bond strength of two self-etching primer adhesive systems. Eur J Orthod 32(3):285-290 